\title{
Expression of the lymphotoxin $\beta$ receptor on follicular stromal cells in human lymphoid tissues
}

\author{
Marianne Murphy ${ }^{1,5}$, Barbara N. Walter ${ }^{4,6}$, Larry Pike-Nobile ${ }^{1}$, \\ Neil A. Fanger ${ }^{2}$, Paul M. Guyre ${ }^{2}$, Jeffrey L. Browning ${ }^{3}$, \\ Carl F. Ware ${ }^{4,7}$ and Lois B. Epstein ${ }^{1}$ \\ ${ }^{1}$ Department of Pediatrics and Cancer Research Institute, University of \\ California, San Francisco, California 94143 \\ 2 Department of Physiology, Dartmouth Medical School, Lebanon, NH 03756 \\ 3 Biogen, Inc., Cambridge, MA 02142 \\ ${ }^{4}$ Division of Molecular Immunology, La Jolla Institute for Allergy and \\ Immunology, San Diego, CA 92121 \\ ${ }^{5}$ Current address: Department of Cell Biology, Human Genome Sciences, 9410 \\ Key West Avenue, Rockville, Maryland 20850, USA \\ ${ }^{6}$ Current address: Department of Biochemistry, University of California, \\ Riverside, California 92521, USA \\ 7 corresponding author: Carl F. Ware, Ph.D., Division of Molecular Immunology, \\ La Jolla Institute for Allergy and Immunology, 10355 Science Center Drive, San \\ Diego, California 92121 tel: 619-678-4655, fax: 619-558-3526, e-mail: \\ carl_ware@liai.org
}

Received 24.9.97; revised 22.12.97; accepted 19.1.98

Edited by D. Green

\begin{abstract}
The lymphotoxin $\beta$ receptor (LT $\beta R$ ), and its ligand, $\mathbf{L T} \alpha 1 \beta 2$, have been proposed to play a key role in the development and organization of lymphoid tissues. The $L T \beta R$ is expressed on a variety of human primary and transformed cells, but strikingly absent on $\mathrm{T}$ or B lymphocytes and primary monocytes or peripheral dendritic cells, although $L T \beta R$ is detected on some myeloid leukemic lines. In the developing thymus LT $\beta R$ is prominent along the trabeculae and into the medulla upto corticomedullary junction. In the spleen, LT $\beta R$ is prominently expressed by cells in the red pulp and along the borders of red and white pulp which colocalizes with reticular stromal cells. The $L T \beta R$ is expressed on a human follicular dendritic cell line, FDC-1, and signals expression of CD54 when ligated with the LT $\alpha 1 / 2$ complex. These results support the concept that directional interactions between $L T \alpha 1 \beta 2$ bearing lymphocytes and $\operatorname{LT} \beta R$ bearing stromal cells are involved in the organization of lymphoid tissue.
\end{abstract}

Keywords: thymus, spleen, reticular dendritic cells, follicular dendritic cells, lymphoid organization, ICAM-1

Abbreviations: C, cortex; DC, dendritic cells; FDC, follicular dendritic cell; H, Hassall's corpuscle; LT $\alpha$, lymphotoxin $\alpha$; LT $\beta$, lymphotoxin $\beta$; LT $\beta \mathrm{R}$, lymphotoxin $\beta$ receptor; $\mathrm{M}$, medulla; $\mathrm{R}$, red pulp; $T$, trabeculae; TNFR, tumor necrosis factor receptor; $V$, blood vessel; $W$, white pulp

\section{Introduction}

The lymphotoxin $\beta$ receptor $(\mathrm{LT} \beta \mathrm{R})$ is a member of the TNF receptor family that has been proposed to play a role in the development and organization of lymphoid tissues (Beutler and vanHuffel, 1994; Ware et al, 1995). Unlike the other TNF receptors (TNFR), LT $\beta$ R does not bind soluble ligand, but rather, a membrane form of lymphotoxin (LT) (Crowe et al, 1994) comprised of one $L T \alpha$ and two LT $\beta$ molecules (LT $\alpha 1 \beta 2)$ (Androlewicz et al, 1992; Browning et al, 1993; 1995). The $\mathrm{LT} \beta$ subunit is a $33 \mathrm{kDa}$ type II transmembrane protein that serves as an anchor for $\mathrm{LT} \alpha$, which lacks a transmembrane domain (Androlewicz et al, 1992; Browning et al, 1991; 1993; Ware et al, 1992). No secreted form of $L T \alpha 1 \beta 2$ has been identified, implying that signaling through the $\mathrm{LT} \beta \mathrm{R} / \mathrm{LT} \alpha 1 \beta 2$ interaction requires cell to cell contact (Browning et al, 1995). $\mathrm{LT} \alpha$ is also secreted as a homotrimer which binds either the 55-60 kDa TNFR (TNFR60, CD 120a) or the 75-80 kDa TNFR (TNFR80, CD120b) (Beutler and vanHuffel, 1994; Ware et al, 1995; Vilcek and Lee, 1991). In contrast, LT $\alpha 1 \beta 2$ does not bind TNFR60 or TNFR80 (Crowe et al, 1994; Browning et al, 1993) and LT $\beta$ R does not bind to secreted LT $\alpha$ homotrimer or to secreted or membrane forms of TNF (Crowe et al, 1994). Thus, the $\mathrm{LT} \beta$ subunit provides the distinct $\mathrm{LT} \beta \mathrm{R}$ specificity to the cell surface LT $\alpha 1 \beta 2$ heterotrimer. Although similar to TNFR60 and TNFR80 in its extracellular ligand binding domain, LT $\beta$ R exhibits little sequence homology with these receptors in its cytoplasmic domain. However, functional similarities between LT $\beta$ R, TNFR80 and CD40 are suggested by the findings that these receptors bind to a related set of signaling molecules, called TRAFs, which constitute a family of zinc ring finger proteins (Mosialos et al, 1995; Nakano et al, 1996). LT $\beta$ R induces a slow apoptotic death in certain adenocarcinomas and tumor growth arrest in vivo (Browning et al, 1996b). Cell death induced by $L T \beta R$ is dependent on TRAF3 (VanArsdale et al, 1997), whereas $\mathrm{NF} \varkappa \mathrm{B}$ activation appears to be mediated by TRAF5 or TRAF2 (Nakano et al, 1996).

While the biological activities and signaling cascades elicited by TNF or LT $\alpha$ homotrimers binding to TNFR60 and TNFR80 have been extensively examined, less is known regarding the function of the $\mathrm{LT} \beta \mathrm{R} / \mathrm{LT} \alpha 1 \beta 2$ interaction. The earliest hint to its function comes from findings that mice rendered deficient in $\mathrm{LT} \alpha$ by targeted gene disruption display a loss of $T$ and $B$ cell organization in the spleen, an absence of Peyer's patches and lymph nodes and deficient germinal center formation with a conspicuous absence of follicular dendritic cells (FCD) and IgG production upon antigenic challenge (De Togni et al, 1994; Banks et al, 1995; Matsumoto et al, 1996a; 1996b; $\mathrm{Fu}$ et al, 1997). Some, but not all, of these phenotypic characteristics have been observed in mice with deficiencies in TNFR60 (Matsumoto et al, 1996b; Pfeffer et al, 
1993; Rothe et al, 1993; Pasparakis et al, 1997), but not in TNFR80 deficient mice (Erickson et al, 1994), suggesting that the $L T \alpha$ homotrimer is not sufficient for the proper organization and function of these tissues. Thus, the binding of $\mathrm{LT} \alpha 1 \beta 2$ to $\mathrm{LT} \beta \mathrm{R}$ is implicated to play a role in lymphoid organogenesis and functional organization of lymphoid tissues. This idea is supported by recent studies demonstrating that LT $\beta$ deficient mice lack Peyer's patches, peripheral lymph nodes, splenic germinal centers and follicular dendritic cells, but retain normal cervical and mesenteric lymph nodes (Koni et al, 1997; Alimzhanov et al, 1997) and that experimental mouse systems using soluble $\mathrm{LT} \beta \mathrm{R}: \mathrm{Fc}$ fusion protein result in deficient splenic architecture (Ettinger et al, 1996) and peripheral lymph node formation (Rennert et al, 1996). Despite this strong evidence, little is known about the cells which express $\mathrm{LT} \beta \mathrm{R}$. Therefore, we examined the expression of $\mathrm{LT} \beta \mathrm{R}$ on a variety of primary human cells and cell lines and developing human lymphoid tissues to identify the cell types involved in the control of lymphoid organization by the $\operatorname{LT} \beta \mathrm{R} / \mathrm{LT} \alpha 1 \beta 2$ interaction.

\section{Results}

\section{Comparison of LT $\beta R$ expression to other TNF receptor family members}

Using immunofluorescence and flow cytometry, we examined the cell surface expression of LT $\beta$ R on a range of human cells of hematopoietic and non-hematopoietic origin and compared its expression to that of TNFR80, TNFR60, CD40 and Fas (CD95) (Table 1). In contrast to TNFR80, or Fas, LT $\beta$ R is not expressed on resting or activated T cells or T leukemias. Both monoclonal and polyclonal goat antibodies to $\mathrm{LT} \beta \mathrm{R}$ failed to react with $\mathrm{T}$ cells, excluding an epitope loss artifact. In contrast to CD40, LT $\beta \mathrm{R}$ is not expressed on an EBV transformed B cell line or a B cell lymphoma. Moderate expression of LT $\beta \mathrm{R}$ was detected on a number of leukemia cell lines, such as U937, HL60 and K562, which represent cells at various stages of myeloid differentiation. It was also found on several cell types of nonhematopoietic origin, such as the high level of expression found on ME-180 cervical carcinoma cells. This pattern of expression is similar, but not identical to that found for TNFR60.

\section{Expression of $\mathbf{L T} \beta \mathbf{R}$ on peripheral blood monocytes and dendritic cells (DC)}

In light of our finding that several human myeloid leukemia lines express $L T \beta R$ we also performed a careful analysis of LT $\beta$ R expression on monocytes and DC obtained by elutriation from human peripheral blood. Figure $1 \mathrm{~A}$ demonstrates the two populations of cells present in elutriated fractions of PBMC enriched for monocytes/DC. These fractions can be divided into CD33+, CD14- and CD33+, CD14+. We used three-color immunofluorescence to evaluate expression of CD83, HLA-DR and LT $\beta R$ on these two populations immediately (day 0 ) or after 2 days in culture (Figure 1B). As previously described (Zhou and Tedder, 1995; O'Doherty et al, 1993), CD33+, CD14- DC express CD83 after 2 days in culture, while CD33+, CD14+ monocytes fail to express this marker. Both populations express HLA-DR, but the DC express high levels of HLADR which are markedly enhanced following 2 days of culture. In contrast, neither population expresses LT $\beta$ R at either time point.

\section{Expression of LT $\beta R$ in developing human thymus}

Given that T cells are the predominant source of the $L T \alpha 1 \beta 2$ ligand (Androlewicz et al, 1992; Browning et al, 1991; Ware et al, 1992) and our previous finding that mRNA for LT $\beta R$ is

Table I Expression of LT $\beta R$ and Related TNF Receptors ${ }^{1}$

\begin{tabular}{|c|c|c|c|c|c|c|}
\hline & \multirow[b]{2}{*}{ Cell type } & \multicolumn{5}{|c|}{ TNF receptor expression } \\
\hline & & $\mathbf{L T} \beta \mathrm{R}$ & TNFR80 & TNFR60 & CD40 & Fas/CD95 \\
\hline $\mathrm{CD}^{+} \mathrm{T}$ cells & Peripheral blood $^{2}$ & - & ++ & - & $-/+$ & + \\
\hline $\mathrm{CD8}^{+} \mathrm{T}$ cells & Peripheral blood & - & ++ & - & - & + \\
\hline II-23 & $\mathrm{CD}^{+} \mathrm{T}$ hybridoma & - & ++ & ++ & - & ++ \\
\hline HUT-78 & $\mathrm{CD}^{+} \mathrm{T}$ lymphoma & - & ++ & ++ & + & +++ \\
\hline Jurkat & $\mathrm{CD}^{+}{ }^{+} \mathrm{T}$ leukemia & - & ++ & + & - & + \\
\hline Molt4 & $\mathrm{CD}^{+} 8^{+}$leukemia & - & + & + & - & + \\
\hline Bcell-3 & B cell EBV positive & - & ++ & + & +++ & +++ \\
\hline BJAB & B cell lymphoma & - & - & + & +++ & ++ \\
\hline U937 & Promonocytic leukemia & ++ & ++ & + & - & + \\
\hline HL60 & Promyleocytic leukemia & + & + & + & - & + \\
\hline K562 & Myelogenous leukemia & ++ & ++ & ++ & - & - \\
\hline WI-38 & Normal lung fibroblast & ++ & - & + & - & + \\
\hline HEK293 & Embroyonic kidney & + & - & + & - & + \\
\hline ME-180 & Cervical carcinoma & +++ & - & + & - & ++ \\
\hline
\end{tabular}

${ }^{1}$ Except for peripheral blood T cells, expression of TNFR was determined by single-color immunofluorescence and flow cytometry using the mAb and methods described in Materials and Methods. Fuorescence signal (peak mean channel) $>20$-fold above staining with normal mouse Ig is denoted with +++; 5-20-fold, ++; 2-4-fold, +; not detected, - . On activated T cells $-/+$ denotes expression of CD40 depends on individual clone of human T cells and the level of CD40 on T cells is typically 10 -fold less than that seen on B cell lines [25]. ${ }^{2} \mathrm{Peripheral} \mathrm{blood} \mathrm{T} \mathrm{cell} \mathrm{subpopulations}$ were detected by dual-color analysis with FITC-labeled anti-CD4 or anti-CD8 and biotin conjugated anti-TNFR and PE-conjugated strepavidin. The peripheral blood $\mathrm{T}$ cell data represents results from seven different donors with no difference noted between genders 
A.

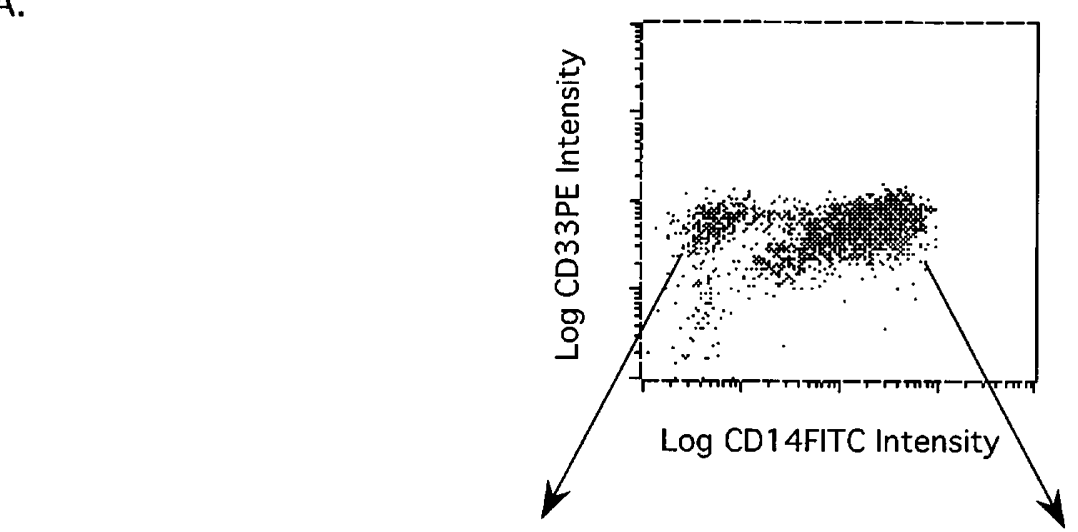

B.

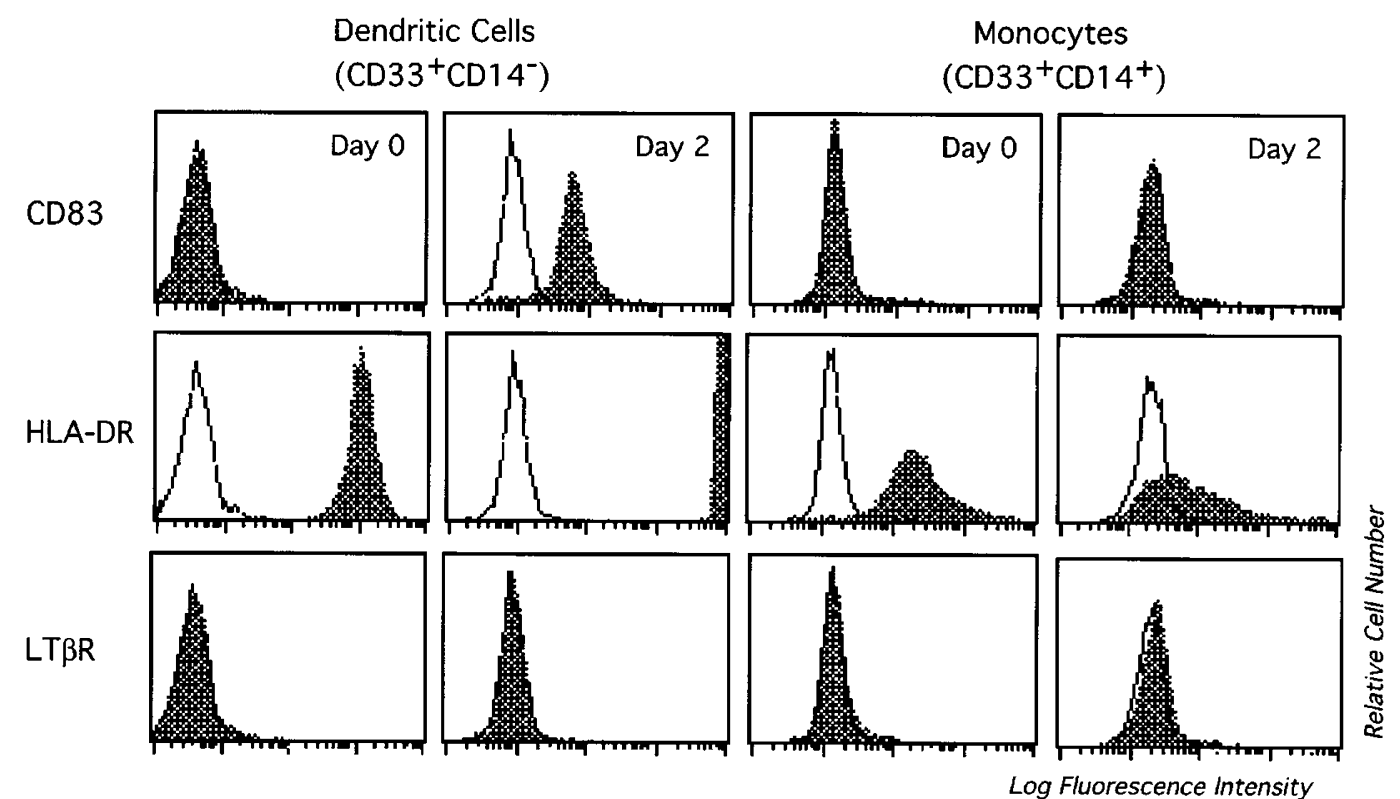

Figure 1 Analysis of LT $\beta R$ expression on human peripheral blood monocytes and DC. Elutriated fractions containing peripheral blood monocytes and DC were stained with PE-conjugated anti-CD33 and FITC-conjugated anti-CD14 to differentiate between the two cell types. Monocytes (CD33+CD14+) and DC $(\mathrm{CD} 33+\mathrm{CD} 14-)$ were individually gated and further analyzed for CD83, HLA-DR or LT $\beta$ R by three-color immunofluorescence. Expression patterns were obtained immediately upon isolation and after two days in culture

expressed in a murine thymic epithelial cell line (Force et al, 1994), we used immunohistochemistry to examine the expression of $L T \beta R$ protein in frozen sections of developing human thymus. In normal postnatal thymus (Figure $2 \mathrm{~A}$ ), $\mathrm{LT} \beta \mathrm{R}$ expression is most prominent in the medulla $(\mathrm{M})$ and along the trabeculae (T). Specific staining for $L T \beta R$ is detected in the stromal rudiment of fetal thymus as early as 14 weeks gestation and distinctly localized by 16 weeks gestation. During development, the trabeculae extend through the cortex and meet with the developing medulla at the corticomedullary junction (von Gaudecker and MullerHermelink, 1980; Kendall, 1989). This is illustrated in Figure $2 \mathrm{~B}$, where $\mathrm{LT} \beta \mathrm{R}$ expressing cells are apparent in the trabeculae, and within the medulla along the corticomedullary junction of a 20 week gestation thymus. In normal thymus, no significant changes in the level or localization of $\mathrm{LT} \beta \mathrm{R}$ expression were observed from 20 weeks gestation to 22 months postnatal.

\section{Colocalization of $\mathbf{L T} \beta \mathbf{R}$ with reticular stromal cells in human thymus}

To define the stromal cell types expressing LT $\beta$ R we stained serial sections of postnatal human thymus with antibodies to reticular dendritic cells, LT $\beta$ R or CD11c, which reacts with tissue macrophages (Lanier et al, 1985; Myones et al, 1988). The results are shown in Figure 3 , where the pattern of staining for $\mathrm{LT} \beta \mathrm{R}(\mathbf{B})$ is similar to that for reticular dendritic cells $(\mathbf{A})$, but not that for CD11c (C). Most notable is the staining along the trabeculae, which are lined with reticular 

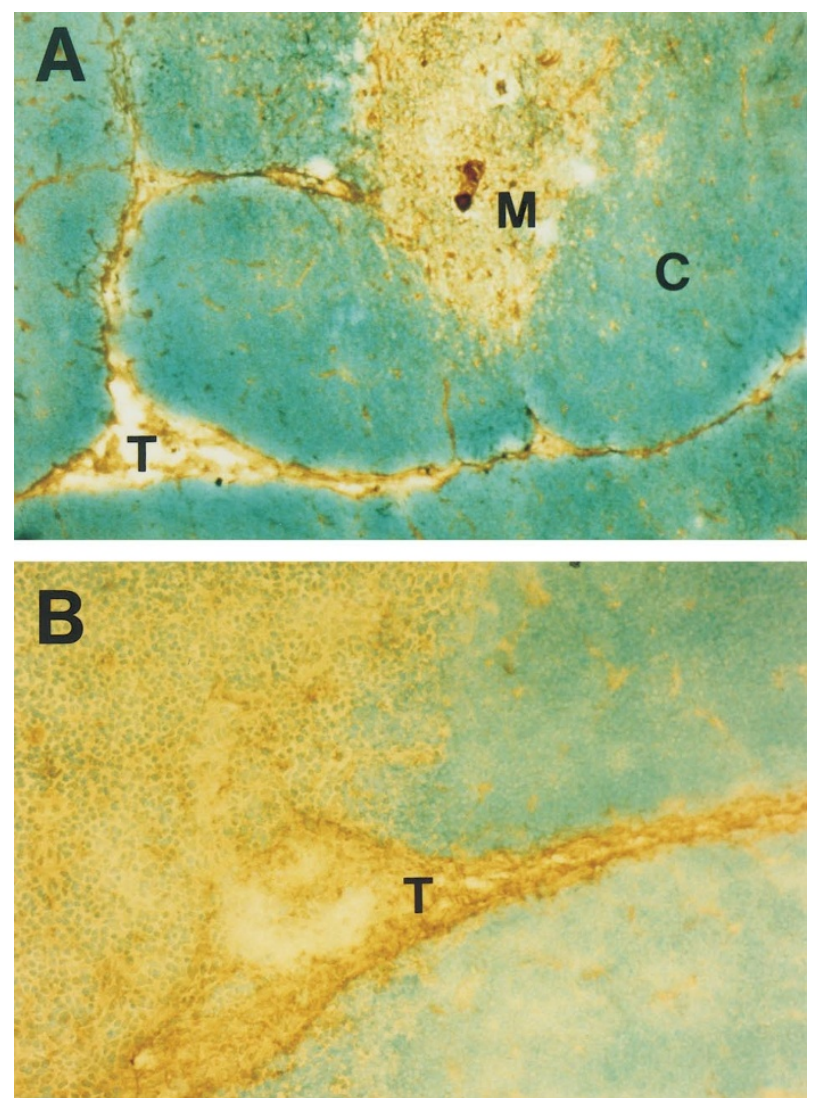

Figure 2 Expression of $L T \beta R$ in developing human thymus. Frozen sections of thymus were stained for $L T \beta R$ expression (brown) and counterstained with methyl green. Sections of thymus are from (A) a 2 month old infant $(145 \times)$, (B) a 20 week gestation fetus $(290 \times)$ Cortex $(C)$, medulla (M) and trabeculae (T) are indicated

dendritic cells (von Gaudecker and Muller-Hermelink, 1980; Kendall, 1989), and the corticomedullary junction (arrows) where $\mathrm{LT} \beta \mathrm{R}$ and the reticular dendritic cell antigens colocalize. In contrast, CD11c reacts with isolated cells along the trabeculae and numerous cells throughout the medulla. Sections of thymus stained with control goat serum or isotyped matched control mAbs showed no staining in cortex, medulla or trabeculae, and only faint, non-specific staining in Hassall's corpuscles.

\section{Expression of $\mathbf{L T} \beta \mathbf{R}$ in developing human spleen and colocalization with reticular dendritic cells}

Given the splenic disorganization observed in LT $\alpha$ deficient mice we examined $L T \beta R$ expression on frozen sections from ten samples of human fetal spleen ranging from 14-22 weeks gestation. Expression of LT $\beta$ R was observed throughout the splenic tissue as early as 14 weeks gestation. By 20 weeks, the developing spleen shows distinct regions of red pulp $(R)$ and lymphocyte-rich white pulp (W). $\mathrm{LT} \beta \mathrm{R}$ is more prominently observed in the red pulp (Figure $4 \mathrm{~A}$ ) and at high power it can be seen concentrated at the R/W border in a stromal pattern of expression (Figure 4B). Sections
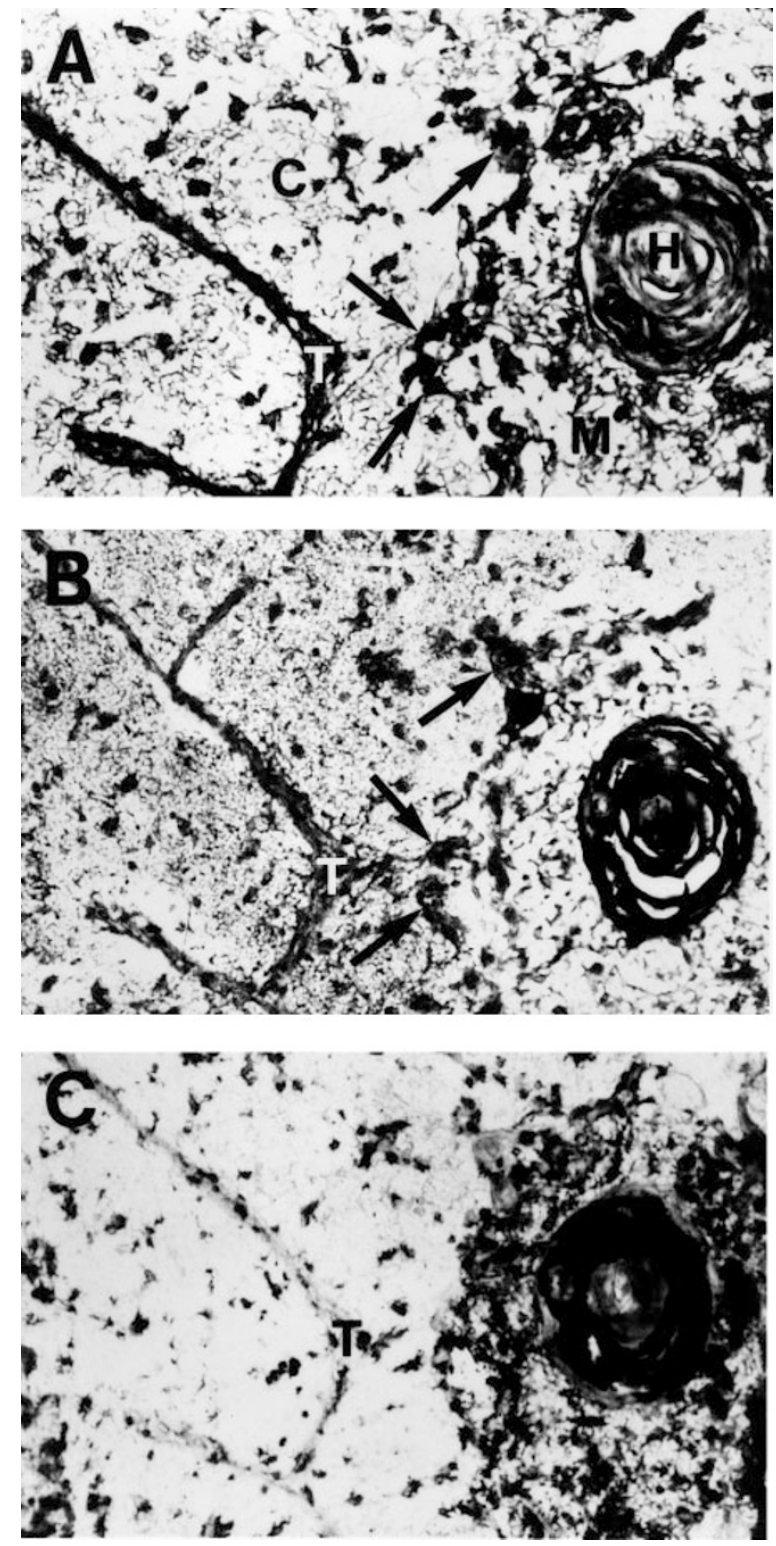

Figure 3 Colocalization of LT $\beta R$ and reticular dendritic cells in human thymus. Serial sections of frozen thymus from a 7 month old child were stained for (A) reticular dendritic cells, (B) LT $\beta$ R or (C) CD11c positive tissue macrophages. Positive staining is indicated by black. All sections are at $580 \mathrm{x}$. Cortex (C), medulla $(M)$, trabeculae $(T)$ and Hassall's corpuscle $(H)$ are identified. Arrows indicate positively stained cells along the corticomedullary junction

of spleen stained with a control goat serum showed no stromal staining and only faint, non-specific staining in central arterioles (Figure 4C). We also examined serial sections of spleen for expression of reticular dendritic cells with anti-LT $\beta \mathrm{R}$ and CD11c (Figure 5). In this 17 week fetal spleen clear demarcation of the red and white pulp had not yet occurred. Specific staining for $\mathrm{LT} \beta \mathrm{R}$ is present on stromal cells throughout the tissue $(\mathbf{B})$ and the pattern of expression is similar to that of the reticular dendritic cell antigen $(\mathbf{A})$, but not for CD11c positive tissue macrophages (C). 

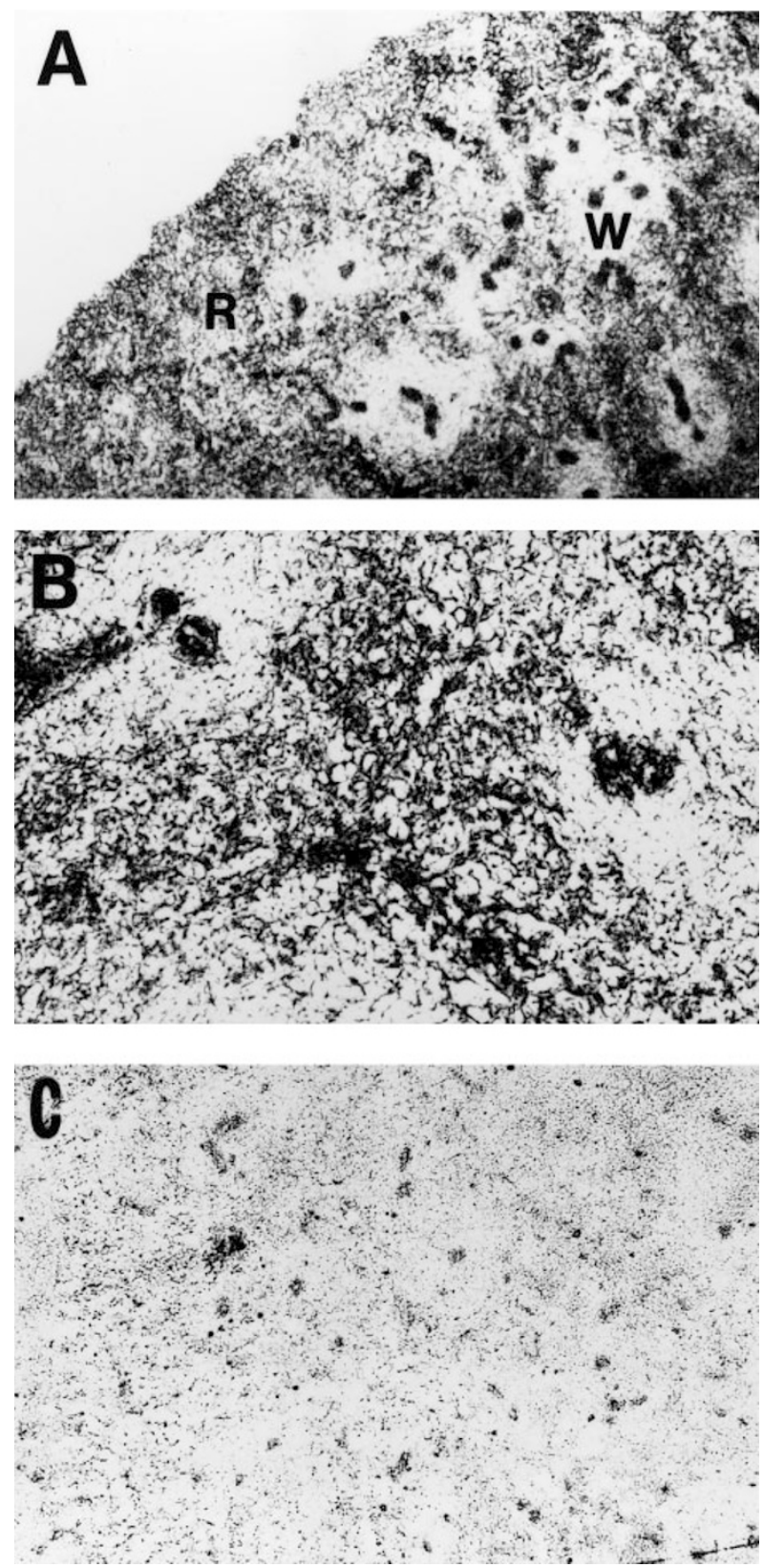

Figure 4 Expression of $L T \beta R$ in developing human spleen. Frozen sections of spleen from a 20 week gestation fetus were stained for $L T \beta R$ expression (black). (A) $145 \times$ and (B) $580 \times$. (C) Section stained with affinity purified control goat antiserum $(145 \times)$. Red pulp $(\mathrm{R})$ and white pulp $(\mathrm{W})$ are indicated

\section{Expression of $\mathbf{L T} \beta \mathrm{R}$ and other TNFR family members on FDC-1}

Our findings that $L T \beta O R$ is expressed on stromal cells rather than lymphocytes in lymphoid tissues is consistent with the results shown in Table 1 and suggests that non-hematopoietic cells such as reticular dendritic cells express this receptor. To verify this hypothesis we used immunofluorescence and flow cytometry to examine expression of LT $\beta R$ and other TNFR family members on a human follicular dendritic cell line, FDC1 , which is representative of this lineage of cells (Figure 6). As
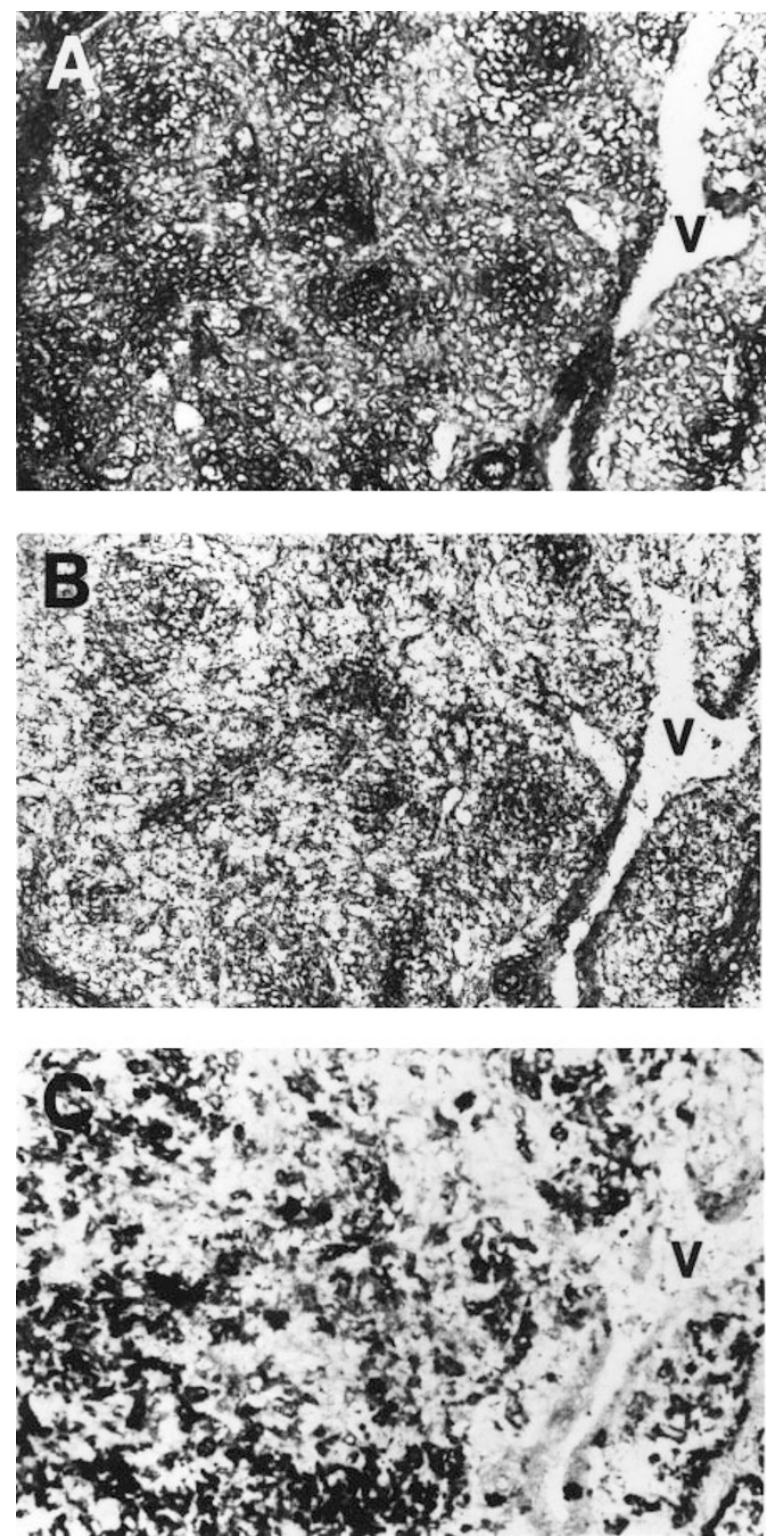

Figure 5 Colocalization of LT $\beta R$ and reticular dendritic cells in human spleen. Serial sections of frozen spleen from 17 week gestation fetus were stained for $(\mathbf{A})$ reticular dendritic cells, (B) $L T \beta R$ or $(\mathbf{C})$ CD11c positive tissue macrophages. Positive staining is indicated by black. All sections are at $580 \times$. A large blood vessel $(\mathrm{V})$ in all sections is indicated

previously described (Clark et al, 1992), this line expresses CD40. These cells also express relatively high levels of $L T \beta R$, Fas and TNFR60, while staining with antibody to TNFR80 was undetectable on FDC-1 when compared to normal IgG control.

\section{Ligation of LT $\beta$ R with LT $\alpha 1 \beta 2$ enhances ICAM-1 (CD54) expression on FDC-1}

To verify that the expression of $L T \beta R$ on FDC- 1 has functional significance, we cultured FDC-1 in the presence of TNF or a soluble form of $L T \alpha 1 \beta 2$ and examined the expression of 


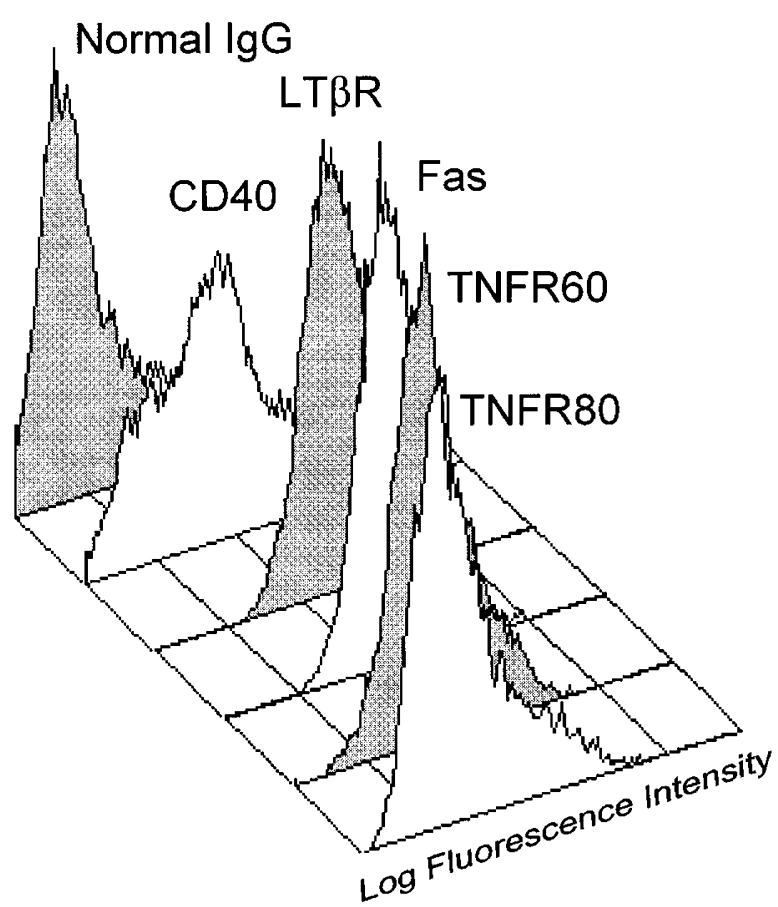

Figure 6 Expression of $L T \beta R$ and other TNFR family members on FDC-1. FDC- 1 cells were harvested by treatment with $20 \mathrm{mM}$ EDTA in saline and stained with the indicated antibodies and $P E$-labeled $F\left(a b^{\prime}\right)_{2}$ goat-anti-mouse Ig. The mean fluorescence channel for: normal mouse IgG, 6; anti-TNFR60, 15; anti-TNFR80, 4; anti-LT $\beta$ R, 31; anti-CD40, 13 and anti-Fas, 31

ICAM-1 by immunofluorescence and flow cytometry (Figure 7). As described (Clark et al, 1992), these cells constitutively express low levels of ICAM-1, which is markedly induced by TNF. We observed that soluble LT $\alpha 1 \beta 2$ also induced ICAM-1 on these cells after only 1 day in culture and that this level was enhanced to that found with TNF by 3 days in culture. As $\mathrm{LT} \beta \mathrm{R}$ is the only known receptor for $\mathrm{LT} \alpha 1 \beta 2$ (Crowe et al, 1994; Browning et al, 1993), these data suggest that LT $\beta R$ ligation results in a functional signal on this cell line.

\section{Discussion}

Characterization of LT $\beta \mathrm{R}$ expression in primary human peripheral blood cells and cell lines indicate that this receptor is not expressed on $\mathrm{T}$ or $\mathrm{B}$ lymphocytes and has a pattern of expression which is different from that of CD40, fas, TNFR60 and TNFR80. LT $\beta$ R is also not expressed on resting, peripheral blood derived monocytes or DC (Figure 1). The fact that it was found at low levels on several myeloid cell lines (Table 1) suggests that LT $\beta R$ may be present on immature or activated cells of the myeloid lineage. The $L T \alpha 1 \beta 2$ ligand for $\mathrm{LT} \beta \mathrm{R}$ exists in a cell surface form which is expressed predominantly by activated $T$ cells, but also by activated $B$ cells and NK cells (Crowe et al, 1994; Androlewicz et al, 1992; Browning et al, 1991, 1993; Ware et al, 1992), suggesting a more restricted function for this receptor through direct cellular interaction with $T$ cells. The fact that $L T \beta R$ is expressed on
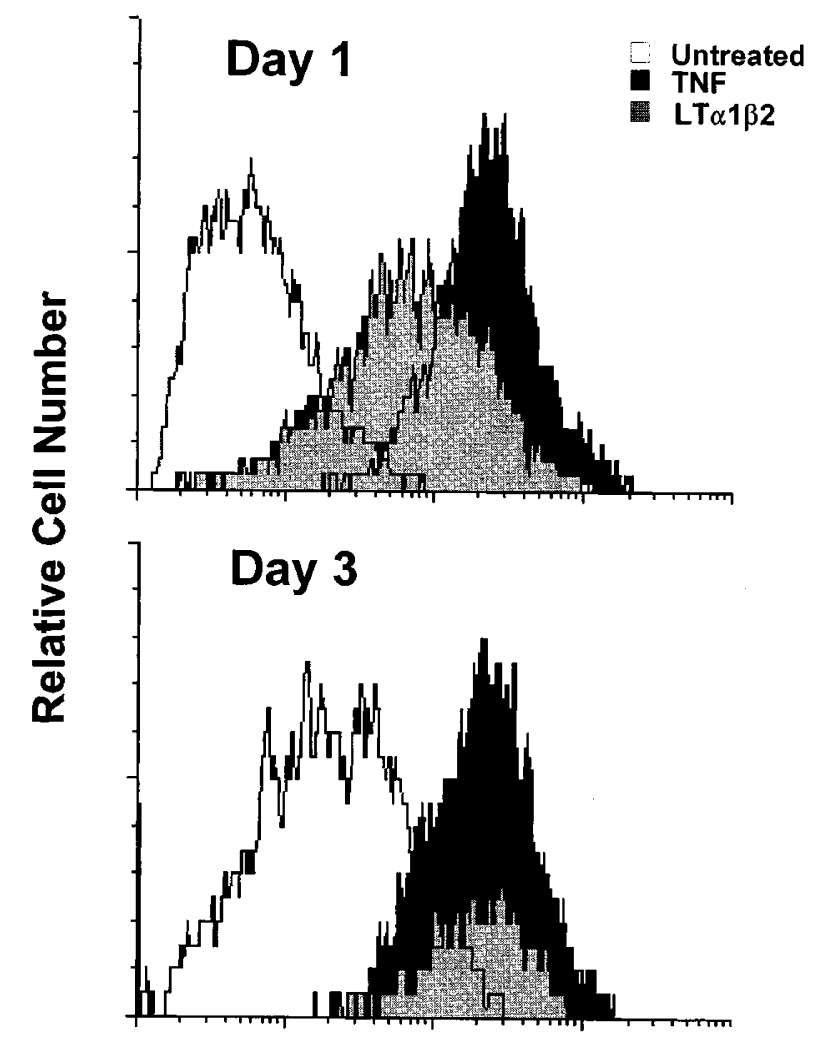

\section{Log Fluorescence Intensity}

Figure 7 Enhancement of ICAM-1 expression by ligation of $L T \beta R$ on FDC-1. FDC- 1 cells were treated with TNF $(0.2 \mathrm{nM})$ or soluble $L T \alpha 1 \beta 2(1.0 \mathrm{nM})$ for $1-3$ days and then harvested with $20 \mathrm{mM}$ EDTA/saline and stained with anti-CD54 (ICAM-1) and PE-labeled $F\left(a b^{\prime}\right)_{2}$ goat-anti-mouse Ig

stromal cells in lynphoid organs, sites where cellular interaction with $\mathrm{T}$ cells is likely to occur, strengthens this hypothesis.

Our finding of $L T \beta R$ expression on stromal cells in human thymus is consistent with a previous report of LT $\beta$ R mRNA expression in murine thymus and in a medullary thymic epithelial cell line (Force et al, 1996). Thus far, activated mature $T$ cells have been shown to express $\mathrm{LT} \alpha 1 \beta 2$. However, mRNA for $\mathrm{LT} \alpha$ and LT $\beta$ have been detected in thymus (Browning et al, 1993), suggesting that immature thymocytes may also express this ligand. Despite these expression patterns, no obvious thymic abnormalities were reported in LT $\alpha$ or LT $\beta$ deficient mice or in mice treated with soluble LT $\beta R$ : Fc fusion protein. It is possible that $L T \beta R$ binds an alternative ligand in developing human thymus or that other cytokines are involved in thymic organogenesis.

Our observation of LT $\beta R$ expression on reticular dendritic cells in the developing human spleen is consistent with the findings that mice transgenic for $L T \alpha$ under the control of the rat insulin promoter develop an accumulation of lymphocytes in the pancreas which strongly resembles de novo lymphoid organogenesis 
(Kratz et al, 1996). Reticular dendritic cells are present in the red pulp and along the marginal areas which form a barrier between the red pulp and white pulp through which lymphocytes traverse (Weiss, 1972). As LT $\beta$ R expression is most prominent in the red pulp it is important to note that the organization of the lymphoid elements within the spleen may involve signals delivered not only by lymphocytes, but also by stromal cells such as reticular dendritic cells. The $\mathrm{LT} \alpha 1 \beta 2$ ligand exists as a cell surface protein on activated lymphocytes and is not secreted (Browning et al, 1991; Ware et al, 1992), whereas LT $\beta R$ is present on reticular stromal cells, suggesting that this ligand/receptor interaction is through direct cellular contact between these two cell types.

FDC are believed to be derived from reticular stromal cells (Yoshida et al, 1995) which accumulate in the lymphoid follicles upon antigen stimulation and play an important role in B cell maturation in lymphoid tissues (Rajewsky et al, 1987; Szakal et al, 1989; Clark and Ledbetter, 1994). The importance of $T$ and $B$ cell interactions in lymphoid follicles has also been recently emphasized by the involvement of CD40 and CD40 ligand (Clark and Ledbetter, 1994), also members of the TNFR/ TNF family. The expression of LT $\beta$ R on the FDC- 1 cell line, as well as our finding that ligation of this receptor results in induction of ICAM-1 on these cells, suggests that the $L T \alpha 1 \beta 2$ ligand on activated T or B cells, also found in lymphoid follicles (Rajewsky et al, 1987; Szakal et al, 1989; Clark and Ledbetter, 1994), interacts with LT $\beta$ R on follicular stromal cells to influence the $B$ cell maturation process. This hypothesis is supported by the recent finding that reconstitution of normal mice with bone marrow from $\mathrm{LT} \alpha$ deficient mice results in loss of FDC clustering, germinal center formation and Ig class switching (Fu et al, 1997). Interestingly, mice deficient in TNF (Pasparakis et al, 1997) and TNFR60 (Matsumoto et al, 1996a,b; Pasparakis et al, 1997) also show failure of germinal center formation and FDC clustering with less dramatic effects on lymphoid organogenesis (Pasparakis et al, 1997). This result is consistent with our finding of TNFR60 on the FDC-1 cell line and suggests that both LT $\beta$ R and TNFR60 signaling are important in FDC clustering and germinal center formation. In constrast to $\mathrm{LT} \alpha$ deficient mice, $\mathrm{LT} \beta$ knockout mice retain cervical and mesenteric lymphnodes and the disorganization of $\mathrm{T}$ and B cells in the spleen is not as severe (Koni et al, 1997; Alimzhanov et al, 1997) suggesting that $\mathrm{LT} \alpha$ may engage another receptor.

In summary, our findings demonstrate that $\mathrm{LT} \beta \mathrm{R}$ is present in human thymus and spleen at early stages of development and is localized to reticular dendritic cells, and not lymphocytes. The early expression and localization of this receptor on stromal cells implies that the interaction with cell surface $\mathrm{LT} \alpha 1 \beta 2$ may be important in organization of these tissues. Additionally, our finding that $\operatorname{LT} \beta \mathrm{R}$ is expressed on FDC-1 helps to explain the abnormalities in FDC clusters and antibody production observed in $\mathrm{LT} \alpha$ and $\mathrm{LT} \beta$ deficient mice and suggests that the $\mathrm{LT} \alpha 1 \beta 2 / \mathrm{LT} \beta \mathrm{R}$ interaction plays an important role in lymphocyte interactions with FDC in the germinal center.

\section{Materials and Methods}

\section{Antibodies}

The following anti-human mAbs were used for flow cytometry: AntiLT $\beta$ R BDA8 mouse IgG1 biotin-conjugated and unconjugated forms (Browning et al, 1996b), anti-TNFR80 M1 rat IgG2b, (Ware et al, 1991), anti-TNFR60 H398 mouse IgG2b (Bender Med Systems, Vienna Austria), anti-CD40 G28-5 mouse IgGI (a gift from E. Clark, University of Washington, Seattle, WA), anti-Fas $\mathrm{CH}-11$ mouse IgM (Pan Vera Inc, Madison, WI), anti-CD4 SK3 mouse IgG1 and anti-CD8 SKI mouse IgG1 FITC-conjugated (Becton Dickinson Immunocytochemistry Systems, San Jose, CA), anti-HLA-DR B8.11.2 mouse IgG2a biotin-conjugated (provided by J. van de Winkel, Utrecht, The Netherlands), anti-CD14 AML-223 mouse IgG2b FITC-conjugated (Medarex, Inc, Annandale, NJ), anti-CD33 4D3 mouse IgG2b PE conjugated (Caltag Laboratories, Inc., San Francisco), anti-CD83 HB$15 \mathrm{a}$ mouse IgG2b biotin-conjugated (a gift from T. Tedder; Duke University Medical Center, Durham, NC), anti-CD54, ICAM-1, mouse IgG1 (Chemicon International, Temecula, CA). Isotype matched control mAb were obtained from Medarex. TRI-COLOR-labeled streptavidin, PE and FITC-labeled $F\left(a b^{\prime}\right)_{2}$ goat-anti-mouse $\mathrm{Ig}$, and $P E$-streptavidin were obtained from Caltag.

For immunohistochemistry serum specific for human LT $\beta$ R was collected from goats immunized with a human $L T \beta R$ : Fc fusion protein (Crowe et al, 1994) and adsorbed with human IgG to remove human Fc reactivity as described (VanArsdale and Ware, 1994). The goat anti$\mathrm{LT} \beta \mathrm{R}$ has no crossreactivity with TNFR60, TNFR80 or Fas (CD95) as measured by competitive radiobinding assays, immunoprecipitation or flow cytometry. Purified serum was used at a 1:1000 dilution (approx. $10 \mu \mathrm{g} / \mathrm{ml}$ ) for immunohistochemistry. Murine mAbs 12B1 (IgG2a, Immunotech, Inc., Westbrook, ME) and anti-gp150,95 (IgG2b, Becton Dickinson), reactive with reticular dentritic cells (Farace et al, 1986) and CD11c on tissue macrophages (Lanier et al, 1985; Myones et al, 1988), respectively, were used at $10 \mu \mathrm{g} / \mathrm{ml}$. Pre-immune goat serum was similarly treated by passage over immobilized human IgG column and used at similar dilutions for controls. Isotype-matched IgG (Organon-Teknika, West Chester, PA) were used as negative controls for mouse mAbs. Purified recombinant TNF and $L T \alpha 1 \beta 2$ (Browning et al, 1996a) were provided by Biogen, Inc.

\section{Cell lines}

The human cell lines HUT-78, Molt4, U937, HL60, K562, WI-38, HEK293 and ME-180 described in Table 1 were purchased from the American Type Tissue Collection (ATCC, Rockville, MD). The B cell-2, -3 and $B J A B$ lines were obtained from $E$. Kieff and G. Mosialos (Harvard University, Boston, MA). B cell-3 was derived from a B cell enriched fraction of human peripheral blood cells infected with Epstein-Barr virus (EBV) carried in the marmoset B95-8 cell line. $B J A B$ is from an EBV negative Burkitt's lymphoma. The human T cell line Jurkat (clone E6-1) was obtained from the NIH AIDS Research and Reference Reagent Program. The human follicular dendritic cell line FDC-1 (Clark et al, 1992) was a gift from E. Clark (University of Washington, Seattle, WA).

\section{Human peripheral blood T cells, monocytes and dendritic cells (DC)}

PBMC from healthy volunteers were obtained by $\mathrm{F} / \mathrm{H}$ density gradient centrifugation (Boyum, 1968). Activated T cells were prepared by culture of PBMC for 5-8 days in RPMI-1640 containing 10\% FCS, anti-CD3 (OKT3, $10 \mathrm{ng} / \mathrm{ml})$ and, after 3 days, with IL-2 $(10 \mathrm{ng} / \mathrm{ml})$ as 
described (Ware et al., 1992). For experiments in Table 1 these activated $T$ cells were distinguished as CD4 or CD8 by immunofluorescence and flow cytometry using FITC-labeled anti-CD4 or CD8 and analyzed for expression of TNFRs with biotinylated $\mathrm{mAbs}$ and PEstreptavidin.

Blood dendritic cells (DC) and monocytes were enriched using countercurrent elutriation as previously described (Fanger et al, 1996). Briefly, PBMC were loaded onto the JE-6B elutriator (Beckman, Palo Alto, $\mathrm{CA}$ ) and $50 \mathrm{ml}$ fractions were collected while increasing the flow rate from 30 to $45 \mathrm{ml} / \mathrm{min}$ at 2500 r.p.m. Elutriated fractions consisting of fewer than $10 \%$ lymphocytes were obtained using this procedure and monocytes (CD33+, CD14+) and DC (CD33+, CD14-) could be distinguished. For experiments described enriched monocyte/DC fractions were analyzed for expression of CD33, CD14 and either CD83, HLA-DR or LT $\beta$ R by three-color immunofluorescence and flow cytometry immediately (day 0 ) or following 2 days of culture in HEPES RPMI 1640 (Gibco, Grand Island, NY) containing 10\% pooled human serum at $5 \times 10^{5}$ cells per well in a 96 well plate.

\section{Human thymus and spleen}

Postnatal thymus was obtained with the assistance of pediatric cardiothoracic surgeons at the University of California Medical Center (San Francisco, CA). Specimens of postnatal thymus from four normal infants ranging in age from 2 days to 22 months and two Down syndrome (DS, trisomy 21) infants aged 4 months and 19 months were examined. Fetal thymus and spleen were obtained from Advanced Bioscience Resources, Inc. (Alameda, CA). Specimens of thymus and spleen from 14, 16, 18, 20 and 22 weeks gestation were examined. Tissue was snap-frozen and stored at $-70^{\circ} \mathrm{C}$. Frozen sections $(8 \mu \mathrm{m})$ of tissue were prepared and fixed in acetone at $-20^{\circ} \mathrm{C}$ for $20 \mathrm{~min}$ on Superfrost slides (Fisher Scientific, Pittsburgh, PA).

\section{Immunohistochemistry}

Immunohistochemistry for human tissues was performed on acetone fixed frozen sections using Vector $A B C$ Elite reagents (Vector Laboratories, Inc., Burlingame, CA). Modifications included the use of $3 \%$ blocking rabbit serum, dilution of antibodies in blocking serum, quenching of endogenous peroxidase in $0.3 \% \mathrm{H}_{2} \mathrm{O}_{2}$ in $\mathrm{MeOH}$ following reactivity with biotinylated secondary antibody and detection of specific peroxidase activity using Nickel-DAB (Pierce, Rockford, IL) and DAB Enhancing Solution (Vector Laboratories). Where indicated, sections were counterstained with $0.1 \%$ methyl green.

\section{Immunofluorescence and flow cytometry}

Cell analysis was performed on a FACScan (Becton Dickinson, San Jose, CA) with more than 5000 cells analyzed per sample. For single color immunofluorescence, cell suspensions $\left(5 \times 10^{5}\right.$ cells in $\left.20 \mu \mathrm{l}\right)$ were incubated for $1 \mathrm{~h}$ at $4^{\circ} \mathrm{C}$ with $20 \mu \mathrm{l}$ of $\mathrm{mAb}$ at optimal concentrations. When necessary, $20 \mu \mathrm{l}$ human $\operatorname{lgG}(12 \mathrm{mg} / \mathrm{ml}$, Sigma, St. Louis, MO) was added to block Fc receptor binding. Following three washes with $200 \mu$ l PBS containing $2 \mathrm{mg} / \mathrm{ml} \mathrm{BSA}$, $40 \mu \mathrm{l}$ of PE-labeled $\mathrm{F}\left(\mathrm{ab}^{\prime}\right) 2$ goat-anti-mouse $\lg (20 \mu \mathrm{g} / \mathrm{ml})$ was added for an additional $1 \mathrm{~h}$. For dual color immunofluorescence with anti-CD4 or anti-CD8 FITC, biotin-conjugated primary mAbs and PE-streptavidin were used. Cells were washed three times, resuspended in PBS-BSA for immediate analysis or PBS-BSA supplemented with $1 \%$ paraformaldehyde for analysis 1 to 7 days later. For three-color analysis cells were incubated with biotinylated primary antibody, washed as above, then followed with TRI-COLOR Streptavidin, PEanti-CD33 and FITC-anti-CD 14, washed and fixed as above.

\section{Acknowledgements}

The authors wish to thank the LT $\beta$ Project Team (Biogen Inc., Cambridge, MA) for valuable reagents, S. VanArsdale for assistance in antibody purification and L. Prentice (Dept. of Anatomy, UC, San Francisco) for helpful advice about photomicroscopy. This work was supported by $\mathrm{NIH}$ grants CA27903 and CA44446 awarded to LBE, ACS grant IM663B and $\mathrm{NIH}$ grant Al33068 awarded to CFW, NIH grant A137212 awarded to PMG and a Scientific Scholar award from the National Down Syndrome Society to MM.

\section{References}

Alimzhanov MB, Kuprash DV, Kosco-Vilbois MH, Luz A, Turetskaya RL, Tarakhovsky A, Rajewsky K, Nedospasov SA and Keffer K (1997) Abnormal development of secondary lymphoid tissues in lymphotoxin $\beta$-deficient mice. Proc. Nad. Acad. Sci. 94: 9302-9307

Androlewicz MJ, Browning LL and Ware CF (1992) Lymphotoxin is expressed as a heteromeric complex with a distinct 33-kDa glycoprotein on the surface of an activated human T cell hybridoma. J. Biol. Chem. 267: 2542-2547

Banks TA, Rouse BT, Kerley MK, Blair PJ, Godfrey VL, Kuklin NA, Bouley DM, Thomas L, Kanangat S and Mucenski ML (1995) Lymphotoxin- $\alpha$-deficient mice. Effects on secondary lymphoid organ development and humoral immune responsiveness. J. Immunol. 155: 1685-1693

Beutler B and vanHuffel C (1994) Unraveling function in the TNF ligand and receptor families. Science 264: 667-668

Boyum A (1968) Isolation of mononuclear cells and granulocytes from human blood. Isolation of monuclear cells by one centrifugation, and of granulocytes by combining centrifugation and sedimenatation at $1 \mathrm{~g}$. Scand. J. Clin. Lab. Invest. 97: $77-89$

Browning JL, Androlewicz MJ and Ware CT (1991) Lymphotoxin and an associated 33-kDa glycoprotein are expressed on the surface of an activated human $T$ cell hybridoma. J. Immunol. 147: 1230-1237

Browning JL, Ngam-ek A, Lawton R, DeMarinis L, Tizard R, Chow EP, Hession C, O'Brine-Greco B, Foley SF and Ware CR (1993) Lymphotoxin $\beta$, a novel member of the TNF family that forms a heteromeric complex with lymphotoxin on the cell surface. Cell 72: 847-856

Browning JL, Dougas L, Ngam-ek A, Bourdon PR, Ehrenfels BX, Miatkowski K, Zafari M, Yampaglia AM, Lawton R and Meier W (1995) Characterization of surface lymphotoxin forms. Use of specific monoclonal antibodies and soluble receptors. J. Immunol. 154: 33-46

Browning JL, Miatkowski K, Griffiths DA, Bourdon PR, Hession C, Ambrose CM and Meier W (1996a) Preparation and characterization of soluble recombinant heterotrimeric complexes of human lymphotoxins $\alpha$ and $\beta$. J. Biol. Chem. 271: $8618-8626$

Browning JL, Miatkowski K, Sizing L, Griffiths DA, Zafari M, Benjamin CD, Meier W and Mackay $F(1996 b)$ Signalling through the lymphotoxin- $\beta$ receptor induces the death of some adenocarcinoma tumor lines. J. Exp. Med. 183: 867-878

Clark EA, Grabstein K and Shy GL (1992) Cultured human follicular dendritic-like cells: growth, characteristics and interactions with B lymphocytes. J. Immunol. 148: $3327-3336$

Clark EA and Ledbetter LA (1994). How B and T cells talk to each other. Nature 367: $425-420$

Crowe PD, VanArsdale TL, Walter BX, Ware CR, Hession C, Ehrenfels B, Browning LL, Din WS, Goodwin RG and Smith CA (1994) Alymphotoxin- $\beta$-specific receptor [see comments]. Science 264: 707-710

De Togni R, Goellner L, Ruddle NH, Streeter PR, Fick A, Mariathasan S, Smith SC, Carlson R, Shornick LP, Strauss-Schoenberger J, Russell LK, Karr R and Chaplin DD (1994) Abnormal development of peripheral lymphoid organs in mice deficient in lymphotoxin. Science 264: 703-706

Erickson SL, de Sauvage FJ, Kikly K, Carver-Moore K, Pitts-Meek S, Gillett N, Sheehan KC, Schreiber RD, Goeddel DV and Moore MW (1994) Decreased sensitivity to tumour-necrosis factor but normal T-cell development in TNF receptor-2-deficient mice. Nature 372: 560-563

Ettinger R, Browning LL, Michie SA, van Ewijk W and McDevitt HO (1996) Disrupted splenic architecture, but normal lymph node development in mice expressing a soluble lymphotoxin- $\beta$ receptor-IgG1 fusion protein. Proc. Natl. Acad. Sci. USA 93: $13102-13107$ 
Fanger NA, Wardwell K, Shen L and Guyre PM (1996) Type-I (CD64) and type-II (CD32) Fc $\gamma$ receptor-mediated phagocytosis by human blood dendritic cells. J. Immunol. 157: 541-548

Farace E, Kieffer N, Caillou B, Vainchenker W, Tursz T and Dohhelar MD (1986). A 93-kDa glycoprotein expressed on human cultured monocytes and dendritic reticulum cells defined by an anti-K562 monoclonal antibody. Eur. J. Immunol. 16: $1521-1526$

Force WR, Walter BX, Hession C, Tizard R, Kozak CA, Browning JL and Ware CF (1996) Mouse lymphotoxin- $\beta$ receptor. Molecular genetics, ligand binding, and expression. J. Immunol. 1995. 1: 155, 5280-5288

Fu Y-X, Molina H, Matsumoto M, Huang G, Min L and Chaplin DD (1997) Lymphotoxin- $\alpha(\mathrm{LT} \alpha)$ supports development of splenic follicular structure that is required for IgG responses. J. Exp. Med. 185: 2111-2120

Kendall MD (1989) The morphology of perivascular spaces in the thymus. Thymus 13: $157-164$

Koni PA, Sacca R, Lawton R, Browning JL, Ruddle NH and Flavell RA (1997) Distinct roles in lymphoid organogenesis for lymphotoxins $\alpha$ and $\beta$ revealed in lymphotoxin $\beta$-deficient mice. Immunity 6: 491-500

Kratz A, Campos-Neto A, Hanson MS and Ruddle NH (1996) Chronic Inflammation caused by lymphotoxin is lymphoid neogenesis. J. Exp. Med. 183: 1461-1472

Lanier LL, Arnuout MA, Schwarting R, Warner NL and Ross GD (1985) p 150,95, third member of the LFA-1/CR3 polypeptide family identified by anti-Leu M5 monoclonal antibody. Eur. J. Immunol. 15: 713-718

Matsumoto M, Lo SF, Carruthers CJL, Min L, Mariathasan S, Huang G, Plas DR Martin SM, Geha RS, Nahm MH and Chaplin DD (1996a) Affinity maturation without germinal centers in lymphotoxin- $\alpha$-deficient mice. Nature 382: 462-466

Matsumoto M, Mariathasan S, Nahm MH, Baranyay E, Preschon LL and Chaplin DD (1996b) Role of lymphotoxin and the type I TNF receptor in the formation of germinal centers. Science 271: 1289-1291

Mosialos G, Birkenbach M, Yalamanchili R, VanArsdale T, Ware C and KieffE (1995) The Epstein-Barr virus transforming protein LMM engages signaling proteins for the tumor necrosis factor receptor family. Cell 80: 389-399

Myones BL, Daizell LG, Hogg N and Ross GD (1988) Neutrophil and monocyte cell surface $p 150,95$ has iC3b-receptor (CD4) activity resembling CR3. J. Clin. Invest. 82: 640-651

Nakano H, Oshima H, Chung W, Williams-Abbott L, Ware C, Yagita H and Okumura K (1996) TRAF5, an Activator of NF-kB and Putative Signal Transducer for the Lymphotoxin- $\beta$ Receptor. J. Biol. Chem. 271: 14661-14664

O'Doherty U, Steinman RM, Peng M, Cameron PU, Gezelter S, Kopeloff L, Swiggard WJ, Pope M and Bhardwaj N (1993) Dendritic cells freshly isolated from human blood express CD4 and mature into typical immunostimulatory dendritic cells after culture in monocyte-conditioned medium. J. Exp. Med. 178: 1067-1076

Pasparakis M, Alexopoulou L, Grell M, Pfizenmaier K, Bluethmann H and Kollias G (1997) Peyer's patch organogenesis is intact yet formation of $B$ lymphocyte follicles is defective in peripheral lymphoid organs of mice deficient for tumor necrosis factor and its 55-kDa receptor. Proc. Nad. Acad. Sci. USA 94: 63196323
Pfeffer K, Matsuyama T, Kundig TM, Wakeham A, Kishihara K, Shahinian A, Wiegmann K, Ohashi PS, Kronke M and Mak TW (1993) Mice deficient for the $55 \mathrm{kd}$ tumor necrosis factor receptor are resistant to endotoxic shock, yet succumb to L. monocytogenes infection. Cell 73: 457-467

Rajewsky K, Forster land Cumano A (1987) Evolutionary and somatic selection of the antibody repertoire in the mouse. Science 238: 1088-1090

Rennert PD, Browning JL, Mebius R, Mackay E and Hochman PS (1996) Surface lymphotoxin $\alpha / \beta$ complex is required for the development of peripheral lymphoid organs. J. Exp. Med. 184: 1999-2006

Rothe L, Lesslauer W, Lotscher H, Lang Y, Koebel P, Kontgen E, Althage A, Zinkernagel R, Steinmetz M and Bluethmann H (1993) Mice lacking the tumour necrosis factor receptor 1 are resistant to TNF-mediated toxicity but highly susceptible to infection by Listeria monocytogenes. Nature 364: 798-802

Szakal AX, Kosco MH and Tew LG (1989) Micro-anatomy of lymphoid tissue during humoral immune responses: structure function relationships. Annu. Rev. Immunol. 7: 91-109

VanArsdale TL and Ware CF (1994) TNF receptor signal transduction: Liganddependent stimulation of a serine protein kinase activity associated with TNFR60. J. Immunol. 153: 3043-3050

VanArsdale TL, VanArsdale SL, Force WR, Walter BX, Mosialos G, Kieff E, Reed JC and Ware CF (1997) Lymphotoxin- $\beta$ receptor signaling complex: role of tumor necrosis factor receptor-associated factor 3 recruitment in cell death and activation of nuclear factor $k$ B. Proc. Natl. Acad. Sci. USA 94: 2460-2465

Vilcek J and Lee TH (1991) Tumor necrosis factor new insights into the molecular mechanisms of its multiple actions. J. Biol. Chem. 266: 7313-7316

Von Gaudecker B and Muller-Hermelink HK (1980) Ontogeny and organization of the stationary non-lymphoid cells in the human thymus. Cell Tissue Res. 207: $287-$ 306

Ware CR, Crowe PD, VanArsdale TL, Andrews LL, Grayson MH, Jerzy R, Smith CA and Goodwin RG (1991) Tumor necrosis factor (TNF) receptor expression in T lymphocytes. Differential regulation of the type ITNF receptor during activation of resting and effector T cells. J. Immunol. 147: 4229-4238

Ware CR, Crowe PD, Grayson MH, Androlewicz MJ and Browning JL (1992) Expression of surface lymphotoxin and turnor necrosis factor on activated T, B, and natural killer cells. J. Immunol. 149: 3881-3888

Ware CF, VanArsdale SL and VanArsdale TL (1995) Cytokines and Receptors of the Lymphotoxin System. In Pathways for Cytolysis. G. Griffiths and J. Tschopp, eds. (Berlin: Springer-Verlag), pp. 175-218

Weiss LA (1972) The spleen. In 'Cells and Tissues of the Immune System', pp. 49 71, Prentice Hall, Englewood Cliffs

Yoshida K, Kaji M, Takahashi T, van-den-Berg TK, Dijkstra CD (1995) Host origin of follicular dendritic cells induced in the spleen of SCID mice after transfer of allogeneic lymphocytes. Immunology 84: 117-126

Zhou LJ and Tedder TF (1995) Human blood dendritic cells selectively express CD83, a member of the immunoglobulin superfamily. J. Immunol. 154: 3821 3835 